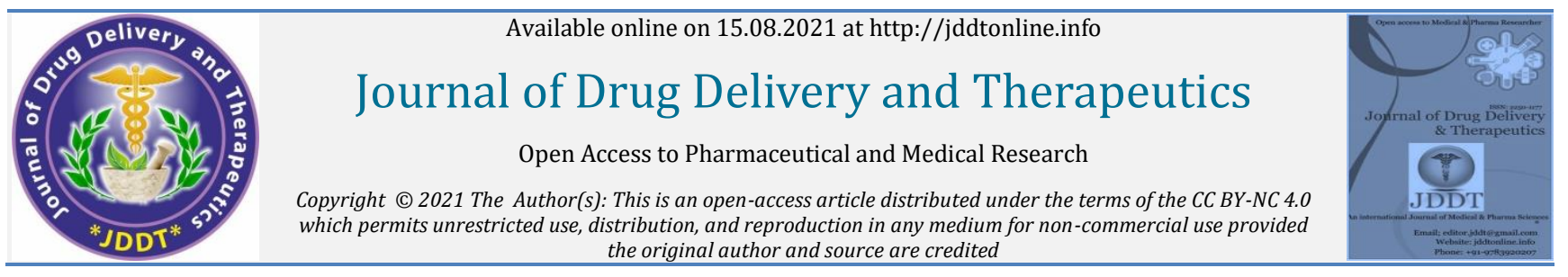

Open Access Full Text Article the original author and source are credited
to

Research Article

\title{
Biochemical Evaluation of Some Liverworts Pigments and Phenolics
}

\author{
K.M. Khalkar, V.B. Kadam (D)* \\ P.G. Department of Botany and Research Centre, M.V.P Samaj's K.T.H.M. College, Nashik, 422002 (M.S.) India
}

\section{Article Info:}

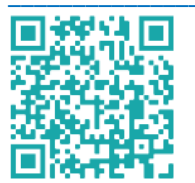

\section{Article History:}

Received 13 June 2021

Reviewed 21 July 2021

Accepted 29 July 2021

Published 15 August 2021

Cite this article as:

Khalkar KM, Kadam VB, Biochemical Evaluation of Some Liverworts Pigments and Phenolics, Journal of Drug Delivery and Therapeutics. 2021; 11(4S):78-80

DOI: http://dx.doi.org/10.22270/jddt.v11i4-S.4958

\begin{abstract}
Three genera viz. Riccia, Plagiochasma and Targionia were studied biochemically. It was found that amount of total chlorophylls and polyphenol content is more in Targionia as compared to Riccia and Plagiochasma Flavonoids are also studied adopting chromatography technique and when the spots viewed under UV were found to be of similar type in Riccia, and Plagiochasma, whereas Targionia showed the present of only one spot,identical to the second spot isolated in Riccia, and Plagiochasma
\end{abstract}

Keywords: Biochemical, Riccia, Plagiochasma, Targionia, pigments, phenolics.

\section{INTRODUCTION:}

The careful review of physiological literature for bryophytes presented in the last few decades devote very little attention to their chemical properties. Moss biochemistry is not completely unknown, however, since their lipid-soluble pigments. ${ }^{1}$ and their proteinaceous compounds ${ }^{2}$ have been investigated in considerable detail and found to be essentially similar to such compounds found in other groups of green plants, ${ }^{3}$ have reported the presence of major flavonoids like flavones 0 , along with glycoside uronic acids and minor amounts of apigenin and luteolin glycosides in Marchantiales. It is suggested that flavonoids are widely distributed within the mosses and that many of these flavonoids may be rare and unusual types which have a narrow systematic distribution ${ }^{4}$. Flavonoids are produced in part from the same intermediates which polymerize to from lignin. In order for a plant to accumulate such compounds it must be able to synthesize C6- C3 Phenylpropoanoid compounds such as phenolic acids. ${ }^{5}$ demonstrated that some bryophytes possessed the ability of carrying out phenol glycosylation reactions. Thus the phenolic chemistry of the bryophytes was found to be worth studying in detail.

Mosses also seem to have potential for studies in biochemical systematic, since they also produce pigments such as chlorophyll and anthocyanins.

Studies were thus undertaken to elucidate the moss biochemistry with respect to pigments and phenolics.

\section{MATERIALS AND METHODS:}

Riccia, plagiochasma and Targionia was collected from Purander Fort near Saswad. All these forms are includes in order Marchantiales. Care was taken to insure that the collection was composed of only one species that no extraneous plant material was included. Liver-works are comparatively small plants. The plant body is dorsiventral gametophyte, independent, either thallose foliose, or all the specimens collected were washed with water to remove soil particles. The gametophytic stages of all the three specimens were collected

Riccia: Plants Small, Greyish, dichotomous, overlapping patches. Dorsal groove deep and narrow near at the apex or slightly concave towards posterior side. Scales prominent. Overlapping deep purple. Rhizoids smooth and tuberculated.Fig.1.

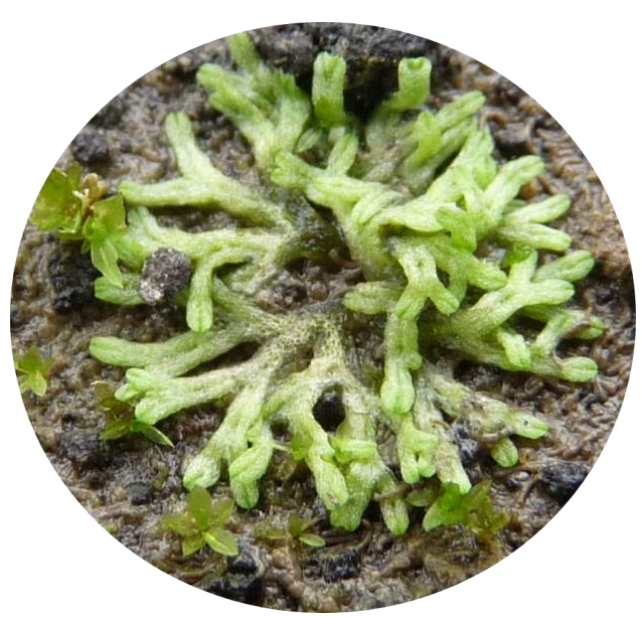

Figure 1: Riccia 
Plagiochasma: Plants are pale-green in colour, ribbonshaped, flat. Thallus apex is forked. Margins purple from ventral side undulate. Rhizoids are simple, male receptacle horse-shoe shaped. Fig.2

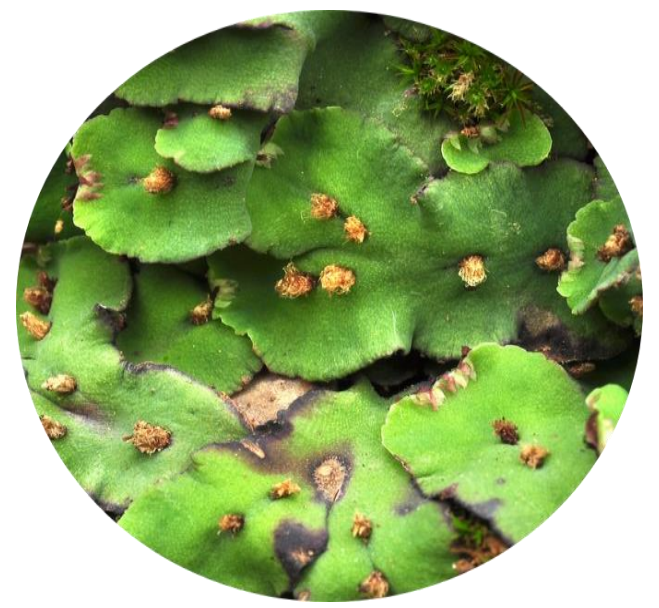

Figure 2: Plagiochasma

Targionia: Plants thallose, terrestrial, prostrate, thallus is simple, with innovations ventrally present near the apex. With distinct areoles on the dorsal surface. Sporophyte is present on ventral side.Fig.3.

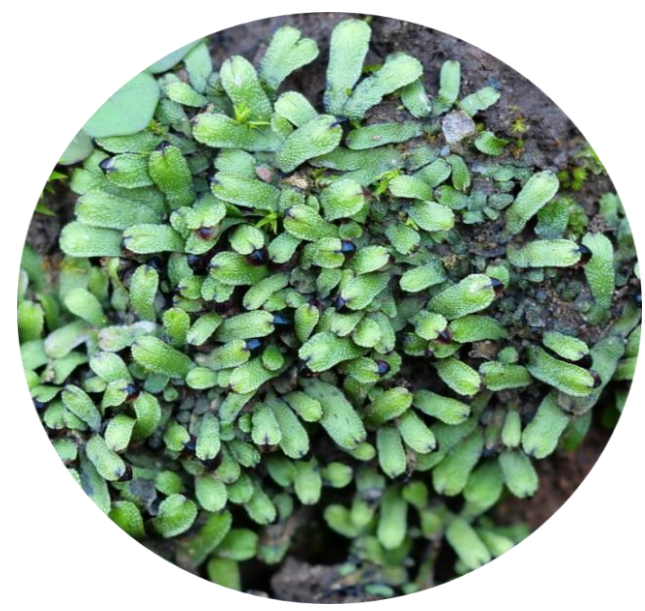

Figure 3: Targionia

\section{METHODS:}

1. Total Polyphenol estimation by Folin method of Swan and Hills

2. Total chlorophyll estimation by Arnon method.

3. Flavonoids

\section{Total polyphenol estimation:}

Total polyphenol was estimated by the Folin method of 6 . One gram of the material was stirred with three, $8 \mathrm{ml}$. aliquots of $80 \% \mathrm{v} / \mathrm{v}$ ethanol over a period of 35 minutes by using a glass homogenizer. The successive extracts were combined and made up to $25 \mathrm{ml}$. A suitable aliquot, say $1 \mathrm{ml}$. of the ethanolic extract was diluted with distilled water to about $8 \mathrm{ml}$; them $0.5 \mathrm{ml}$ of Folin-phenol reagent was added and the contents were well mixed. After 3 minutes, $1 \mathrm{ml}$ of saturated sodium bicarbonate solution was added and the final volume was made up to $10 \mathrm{ml}$. with distilled water. The tubes were thoroughly shaken and the colour development was measured at $725 \mathrm{~nm}$ after standing for 60 minutes. A standard curve was prepared using standard tannic acid and all the concentrations were expressed in terms of micrograms of this compound 7 .

\section{Total Chlorophyll estimation:-}

The total chlorophylls were estimated by the method given by ${ }^{8}$. One gm. of the leaves was crushed in a mixture of $80 \%$ acetone (v/v) with $\mathrm{NH}_{4} \mathrm{OH}(4 \mathrm{ml} / \mathrm{L})$ and a pinch of $\mathrm{MgCo}_{3}$. The homogenate was filtered through Buchner funnel. The filtrate was made to a volume of $10 \mathrm{ml}$. by adding $80 \%$ acetone. The absorbance of this filtrate was recorded at 663 and $645 \mathrm{~nm}$ on spectronic 20 colorimeter.

\section{Flavonoid-}

A small amount of plant tissue was immersed in 2 M HCL and heated in a test tube for $30-40 \mathrm{~min}$ at $100^{\circ} \mathrm{C}$. The cooled extract was then filtered and extracted with ethyl acetate since the solution was coloured (either because the originala) tissue was coloured with anthocyanin or because colour was formed from anthocyanidin during acid treatment. The aqueous extract is further heated to remove the last traces of ethyl acetate and re extracted with a small volume of amyl alcohol. The ethyl acetate is concentrated to dryness, taken up in 1-2 drops of ethanol and aliquots chromatographed one dimensionally on a paper Chromatogram using, Forestal solvent system (acetic acidconc. Hc1- Water:30 :3:10) The spots obtained were observed under ultra violet light.

\section{RESULTS ANDDISCUSSION:}

Table 1: Polyphenol content in $\mathrm{mg} / \mathrm{gm}$ fresh wt of material \pm Std. error.

\begin{tabular}{|l|l|l|}
\hline $\begin{array}{l}\text { Sr. } \\
\text { No. }\end{array}$ & $\begin{array}{l}\text { Name of plant } \\
\text { material }\end{array}$ & $\begin{array}{l}\text { Concentration of } \\
\text { Polyphenol Std. error }\end{array}$ \\
\hline 1. & Riccia & $28.529 \pm 0.04$ \\
2. & Plagiochasma & $23.875 \pm 0.07$ \\
3. & Targionia & $20.785 \pm 0.27$ \\
\hline
\end{tabular}

* Each reading is mean of three replicates.

Table 2: Amount of chlorophyll a. chlorophyll b.

Total Chlorophyll in $\mathrm{mg} / \mathrm{gm}$ fresh wt. of the material \pm std. error.

\begin{tabular}{|l|l|l|l|l|}
\hline $\begin{array}{l}\text { Sr. } \\
\text { No. }\end{array}$ & $\begin{array}{l}\text { Plant } \\
\text { Material }\end{array}$ & Chl.a & Chl.b & $\begin{array}{l}\text { Total } \\
\text { Chlorophyll }\end{array}$ \\
\hline 1. & Riccia & 0.66245 & 0.44805 & 1.1096 \\
2. & Plagiochasma & 1.04755 & 0.32735 & 1.3384 \\
3. & Targonia & 1.52026 & 0.81562 & 2.33436 \\
\hline
\end{tabular}

Each reading is mean of three replicates

Table 3: Flavonoids:-

\begin{tabular}{|c|l|l|l|}
\hline $\begin{array}{c}\text { Sr. } \\
\text { No. }\end{array}$ & $\begin{array}{l}\text { Name of the } \\
\text { Plant }\end{array}$ & $\begin{array}{l}\text { Rf. } \\
\text { Values }\end{array}$ & $\begin{array}{l}\text { Colour- under UV } \\
\text { light }\end{array}$ \\
\hline 1. & $\begin{array}{l}\text { Riccia- Spot-1 } \\
\text { Spot-2 }\end{array}$ & 0.77 & Yellow Fluorescing \\
2. & $\begin{array}{l}\text { Plagiochasma } \\
\text { Spot -1 }\end{array}$ & 0.90 & Yellowish Green \\
& $\begin{array}{l}\text { Spot 2 } \\
\text { Targionia }\end{array}$ & 0.86 & Yellow \\
3. & Spot 2 & 0.83 & Yellowish Green \\
\hline
\end{tabular}


From the above results it is clear that the amount of total polyphenols is more in Targionia as compared to Riccia and Plagiochasma (Table- 1).

It is also obvious from Table-2 that the amount of Pigments Chlorophyll: a. Chlorophyll: b and total chlorophylls are more in Targionia with respect Riccia and Plagiochsma. Chloroplasts have been postulated to play a special role in the synthesis of phenolic compounds either in the stroma or tightly associated with thylakoid membranes ${ }^{9}$.An interesting feature of bryophyte is that they are relatively free from attack by parasitic microorganisms. Herbarium specimens of these plants need no special treatment like those of higher plants ${ }^{10}$.

The cause of this may be anatomical, immunological or may be due to the presence of antimicrobial activity of some factors. There is a need for more information on these points. The number of compounds, with limited information on their chromatographic characteristics is presented in Table-3. Flavonoid has been detected in all the three genera studied. The chromatograms when exposed to UV light Showed that Riccia and Plagiochsma possessed the same types of flavonoids (Table-3) whereas Targionia showed the presence of just one flavonoid. Flavonoids are produced in part from the same intermediates which polymerize to form lignin.

It has been recognized for many years that mosses can produce compounds to strengthen in the cell walls as does the lignins. The precise type of flavonoid obtained in our results needs further investigations. In addition to their unusual presence, there is evidence that their intracellular localization may also be unusual 4 It is suggested that flavonoid are widely distributed within the mosses and many of these may be rare and of unusual type which have a narrow systematic distribution. 4 .

\section{REFERENCES:}

1. Freeland and R.O. Plastid pigments of gametophyte and saprophyte of music plant Physic. 1957; 1(32):64-66. https://doi.org/10.1104/pp.32.1.64

2. Black W.A. Cornkili. W. J. and Woodward F. Npreliminary investigation on the chemical composition of Sphagnum moss and peat. J.Appl.Chem. 1955; 5:484-492 https://doi.org/10.1002/jctb.5010050907

3. Markham and Porther-Flavonoids of the liverwort Marchantia Polymorpha. Phytochemistry. 1974; 13:1937-1942. https://doi.org/10.1016/0031-9422(74)85120-4

4. Mc Clure J.W. and Miller H.A. Moss Chemo taxonomy: A survey for flavonoids and the taxonomic implications. Nova Hedwigia. 1967; 14:111-125.

5. Pridham, The phenol glucosylation reaction in the plant kingdom.Phytochemistry.1964; 3:493-497. https://doi.org/10.1016/S0031-9422(00)88026-7

6. Swan and Aahills-Phenolic constituents of Prunusdomestica J. The quantitative analysis of phenolic constituents'. Sci. Fd. Agr. 1955; 10:63- 68 https://doi.org/10.1002/jsfa.2740100110

7. Shah and Subbaiah, Hormonal effect on polyphenol accumulation in Cassia tissue cultured in vitro can. J. Bot. 1975; 54:1240-1245. https://doi.org/10.1139/b76-134

8. Arnon-Copper enzymes in isolated chloroplast :Polyphenol oxidase in Betavulgaris L. Plant Physiol. 1949; 24:1- 15. https://doi.org/10.1104/pp.24.1.1

9. Mc clure-Recent advances in Phytochemistry, 1979; 12:525-588.

10. Mc Cleary and Walking, Mosses and antibiosis. Rev. Bvryolet Lichenol. 1966; 23-38 